\title{
Prolonging Payment Deadlines of Real Estate Tax Instalments to Entrepreneurs in Connection with Covid-19 in Poland: Basic Rules, Consequences of the Application of the Mechanism and Selected Disadvantages of Tax Resolutions
}

\author{
Mariusz Popławski* - Mariusz Charkiewicz**
}

\footnotetext{
* Mariusz Popławski, Full Professor, Dean of the Faculty of Law of the University of Białystok, Poland, ORCID: https://orcid.org/0000-0003-1403-3033

** Mariusz Charkiewicz, Doctor of Legal Sciences, Assistant at the Faculty of Law and Administration, University of Warmia and Mazury in Olsztyn, Solicitor, Poland, ORCID: https://orcid.org/00000001-9363-988X
}

\begin{abstract}
The primary aim of this article is to present fundamental principles resulting from Article $15 \mathrm{q}$ of the Covid Act - which contains the legal basis for passing tax resolutions - according to which the municipality councils may prolong to entrepreneurs payment deadlines of certain instalments in real estate tax. This paper discusses the consequences of introducing these preferences, as well as certain flaws of the tax resolutions adopted on the basis of the aforementioned regulation of the Act on Covid. The flaws were detected on the basis of the analysis of the resolutions adopted by regional accounting chambers finding shortcomings in the resolutions of municipality councils adopted on the basis of the aforementioned provision of the Act on Covid.
\end{abstract}

Keywords: tax law, real estate tax, tax resolutions, prolonging payment deadlines, regional accounting chambers, Covid

\section{Introduction}

As a result of the coronavirus epidemics the authorities introduced, among other things, a possibility of tax resolutions aimed at introducing tax exemptions and prolonging deadlines for instalments in the real estate tax for entrepreneurs whose financial liquidity worsened in connection with negative economic consequences caused by the Covid. The preferences result from Articles 15p and 15q of the Act of March 31, 2020 on amending the Act on Covid.

The primary aim of this article is to present fundamental principles resulting from Article $15 \mathrm{q}$ of the Covid Act, which contains the legal basis for prolonging payment deadlines in real estate tax, which was mentioned above. Article $15 \mathrm{q}$ of the Act on Covid includes the legal basis for passing tax resolutions according to which the municipality councils may prolong to entrepreneurs payment deadlines of certain instalments in real estate tax. This paper will also discuss consequences of introducing these preferences, as well as certain flaws of the tax resolutions adopted on the basis of the aforementioned 
regulation of the Act on Covid. The flaws were detected on the basis of the analysis of the resolutions adopted by regional accounting chambers finding shortcomings in the resolutions of municipality councils adopted on the basis of the aforementioned provision of the Act on Covid. The work on those faults was written on the basis of another article by Popławski \& Charkiewicz (2020b).

\section{Literature overview}

The discussed preference is analysed in several papers. In some of them, we deal with the presentation of this preference in relation to other allowances introduced in connection with the Covid pandemic. (Dowgier, 2020a; Etel, 2020a) In others, the subject of analysis is the problems that this preference may cause in practice. (Dowgier, 2020b; Popławski \& Charkiewicz, 2020a; Popławski \& Charkiewicz, 2020b; Kamiński, 2020) In other studies, the problem of prolonging payment deadlines of real estate tax instalments is presented in a broader perspective as tax reliefs (Etel, 2020b) and in the perspective of other tax resolutions in which specific tax preferences are introduced. (Popławski, 2011)

\section{Research}

The study uses primarily the dogmatic-analytical method. It is related to the verification and analysis of the regulations concerning the described institution as well as the literature concerning the issue of prolonging payment deadlines of real estate tax instalments. As part of this study, the following research hypotheses will be verified: commune councils have the right and not the obligation to introduce prolonging payment deadlines of real estate tax instalments; commune councils are obliged to comply with certain limitations resulting from the act; the introduction of the tax relief will trigger consequences, especially regarding public aid; and the introduced tax resolutions probably contain certain shortcomings identified by the supervisory authority, i.e. the regional accounting chambers.

\section{Discussion}

\subsection{The essence and character of prolonging the deadline of paying instalments in real estate tax for entrepreneurs introduced on the basis of the provisions of the Act on Covid}

In compliance with Article 15q Paragraph 1 of the Act on Covid, a municipal council may prolong, through a resolution, payment deadlines of real estate tax instalments, due in April, May and January 2020 for no longer than by September 30, 2020 (Act on Covid, Article 1 item 14) for selected groups of entrepreneurs, whose financial liquidity deteriorated in connection with the negative economic consequences caused by 
Covid-19. Moreover, Paragraph 2 of the regulation points out that in the resolution discussed in Paragraph 1, a municipal council may prolong the deadline for instalments mentioned in Paragraph 1, also for other entities whose financial liquidity worsened because of the negative economic consequences caused by Covid-19, namely non-government organisations mentioned in Article 3 Paragraph 2 of the Act of April 24, 2003 on the activity of public good and volunteering, as well as the entities named in Article 3 Paragraph 3 of the aforementioned Act. ${ }^{1}$

The regulation refers to an institution which has not so far operated in the regulations referring to real estate tax. (Etel, 2020a, p. 10) Preferences which could be introduced on the basis of the Act on local taxes by municipal councils through tax resolutions were differentiation of tax rates (Article 5 Paragraph 2-4), as well as tax exemptions (Article 7 Paragraph 3). An institution similar to that in Article $15 \mathrm{q}$ of the Act on Covid finds its place in Article 37 Paragraph 4a of the Act on Tax Ordinance. In accordance with this regulation, the payment deadline for collectors is the day following the last day, when, according to the provisions of tax law, the payment should be done, unless the deciding authority of a competent unit of local government scheduled a later deadline. Thus the provision regulates the institution of prolonging the payment deadline for collectors, which also may be used by the municipal council, and which was also realised in the form of a tax resolution. However, literature also contains a statement that this provision regulates "prolonging the deadline" since it points out that the deadline for collectors may be extended in a resolution of the municipal council. (Etel, 2020b)

The institution of prolonging payment deadlines lies also in the competence of the Minister of Finance and is applied through a regulation issued on the basis of the provisions of the Act on Tax Ordinance. In accordance with Article 50 of the Act on Tax Ordinance, the minister competent in public finance may, by regulation, extend the deadlines provided for in the provision of tax law except the deadlines determined in Articles 68-71, Article 77 Paragraph 1, Article 79 Paragraph 2, Article 80 Paragraph 1, Article 87 Paragraph 3 and 4, Article 88 Paragraph 1 and Article 118, defining groups of taxpayers for whom the deadlines were prolonged, types of activities the deadline of implementation of which was extended, as well as the day of expiry of the prolonged deadline.

In terms of the results of the institution of prolonging payment deadline, the mechanism of deferment of deadline is similar. In compliance with Article 48 Paragraph 1 of the Act on Tax Ordinance, in cases justified by an important interest of the taxpayer or a public interest, on the taxpayer's request a tax authority may defer the deadlines provided for in the provisions of the tax law, except for the deadlines determined in Article 68-71, Article 77 Paragraph 1-3, Article 79 Paragraph 2, Article 80 Paragraph 1, Article 87 Paragraph 3 and 4, Article 88 Paragraph 1 and Article 118. However, in this case the action may be individual and applied, in the context of real estate tax, by a wójt or mayor (city president).

Whereas the scope of this paper concerns entrepreneurs being payers of the real estate tax, the subject of the further analysis will be only the regulation resulting from Article 15q para 1 of the Act on Covid. 
It is important to underscore that the mechanism regulated in Article $15 \mathrm{q}$ of the Act on Covid, like that included in Article 15p of the aforesaid Act, is a special regulation, which authorises but does not oblige municipality councils to introduce a particular preference. (Dowgier, 2020a, p. 7) Prolonging the deadline, which is based on Article 15q of the Act on Covid, may be applied in particular legal and time frames, which constitute limits for municipal councils. One of the limits concerns the possibility of applying the institution in reference to real estate tax only. For comparison, the institutions in Article 47 Paragraph 4a, Article 48 and Article 50 of the Act on Tax Ordinance have a much wider application, for they may be applied for all taxes, but also for other due payments to which the Act on Tax Ordinance is not applicable.

Moreover, the instrument may be applied exclusively in reference to particular payment deadlines of real estate tax instalments for 2020, i.e. those due to be paid in April, May and June 2020. In case of taxpayers who are legal persons, the regulation is applicable in reference to three instalments of real estate tax, which were due by April 15, May 15 and June 15, 2020. In accordance with Article 6 Paragraph 9 Point 3 of the Act on local taxes and fees, legal persons, organisational units, as well as companies without legal personality, organisational units of the Agricultural Property Agency, as well as organisational units of the National Forest Holding "The State Forests", are obliged to pay the real estate tax calculated in the declaration, without a request, to the account of an appropriate municipality, in instalments proportional to the duration of the tax obligation, within the period before the $15^{\text {th }}$ of each month, but for January before January 31 . In case of taxpayers being natural persons, the regulation only refers to the instalment of the real estate tax which was due by May 15, 2020. For in accordance with Article 6 Paragraph 7 of the Act on local taxes and fees, the real estate tax is payable in instalments proportional to the duration of the tax obligation, by March 15, May 15, September 15 and November 15 of the tax year. Moreover, the instrument may be applied only in reference to particular payment deadlines of real estate tax instalments for 2020, i. e. payable in April, May and June 2020.

Thus, in Article 15q of the Act on Covid, the legislator did not provide a basis to prolong estate tax payment deadlines due in, for example, the remaining months JulyDecember 2020 and in subsequent years. There is no basis either for prolonging deadlines of the instalments which had been already payable in the period January-March 2020. There are also no grounds to prolong the deadline of real estate tax instalment due in the period April-June 2020, which at the moment of the publication of the resolution had expired. In this case we would deal with the prolonging of the deadline of tax arrears, which should be distinguished from the payment deadline of the instalments which have not expired. Obviously, the legislator could introduce in Article 15q of the Act on Covid a basis for prolonging payment deadlines of tax arrears, which, however, they did not. For if the legislator's will was also enabling a municipality council to apply this application in reference to tax arrears, they should record it explicitly. On the grounds of Article 67a Paragraph 1 Points 1 and 2 of the Act on Tax Ordinance, the legislator applied a similar mechanism, i.e. deferment of the tax payment deadline as well as tax arrears, explicitly and separately commenting on each of these due sums, for which the deferment of payment 
deadline is applicable. ${ }^{2}$ Literature also suggests that what can be prolonged on the basis of Article $15 \mathrm{q}$ of the Act on Covid is only the deadline which has not expired yet, since reaching for the institutions regulated in the Tax Ordinance, it is worth noting that along with the date of the payment deadline expiry, tax arrears emerge which cannot have any payment deadline. (Dowgier, 2020a, p. 13)

Another restriction introduced in Article $15 \mathrm{q}$ of the Act on Covid determines the final deadline where the real estate tax instalments which have been prolonged should be paid. The deadline cannot be later than September 30, 2020. Thus, the resolutions which prolong the deadline of payment of the instalments of the tax due in the months AprilJune, for example, until October 31, 2020, will be against the law.

The wording of the adopted resolution including extending the payment deadline of the tax instalments on the basis of Article 15q of the Act on Covid must be of an objectsubject nature and should be automatic, like in the case of tax resolutions introducing tax exemptions adopted on the basis of Article 15p of the Act on Covid.

\subsection{Consequences of prolonging payment deadlines of real estate tax instalments in connection with the provisions of the Act on Covid}

Introducing a resolution adopted on the basis of Article $15 \mathrm{q}$ of the Act on Covid triggers certain consequences, in particular on the part of the municipality, although on the part of the taxpayer there will also be certain obligations.

In the context under scrutiny it is important to pose a question if a municipality introducing the prolongation of payment deadline will bear negative effects thereof, in connection with the fact that this reduces the resources acquired from the state as a general subvention. It seems that this issue should be referred to negatively, even though it is not an obvious question. In accordance with the modified provisions of Article 32 Paragraph 3 of the Act of November 13, 2003 on the incomes of local government units, in order to determine the compensatory part of the general subsidy and payments, as well as the sum mentioned in Article 21a Paragraph 1 Point 3, we should assume the incomes which a local government unit may gain from the agricultural tax, using the average purchase price of rye to calculate it, and from the forest tax the average sale price of wood, announced by the President of the Statistics Poland, and in case of other taxes calculating them with the upper limits of tax rates in force in a particular year. The income which a local government unit may obtain also includes the financial consequences resulting from the application of tax reliefs and relieves in paying off tax obligations in the form of cancelling the whole or

\footnotetext{
In accordance with Article 67a Paragraph 1, a tax authority, on request of the taxpayer, subject to Article 67b, in cases justified by an important interest of the taxpayer or public interest may:

1. defer the tax payment deadline or spread the tax payment in instalments

2. defer or spread in instalments tax arrears together with interest for delay or interest for tax prepayment not paid in due time
} 
part of tax arrears, which are provided for in the provisions of the tax law. Thus, the regulation shows directly that the consequences do not include reliefs in tax obligation payments in the form of deferment of payment deadlines and spreading the payment out in instalments. The justification for the amendment proposal of the aforementioned provision of the Act on income of local government units shows that the change consists in not including at calculating subsidies and payments financial consequences resulting from applying the reliefs, provided for in the provisions of the tax law, in paying off the tax obligations in the form of deferment of tax payment and spreading the payment out in instalments. It is important from the point of view of tax reliefs granted by the authorities of local government units. This solution is connected with counteracting the effects of the Covid-19 epidemics, because within their tax competences, municipalities grant taxpayers reliefs in paying off their tax obligations. It is important to underscore that prolonging the payment deadline resulting from tax resolutions adopted on the basis of Article $15 \mathrm{q}$ of the Act on Covid results in a consequence practically identical to that resulting from the deferment of payment deadline constituting a relief in paying off tax obligations. Thus, if in the light of Article 32 Paragraph 3 of the Act on incomes of local government units there are no reliefs in payment involving deferring payment deadlines, there should not be situations either where the prolongation of payment deadlines of real estate tax instalments mentioned above occurs.

The introduction of the aforementioned prolongation of payment deadlines, which will be used by entrepreneurs, will result in the necessity of the municipality to show the aid it was granted. For there is no doubt that the prolongation will be public aid. In accordance with Article 15 zzzh Paragraph 1 Point 1 of the Act on Covid, the aid mentioned in Article 15m, Article 15p, Article 15q, Article 15za Paragraph 2, Article 15zzb-15zze, Article 15zze, Article 31zo and Article 31zy, according to the conditions included in the Communication of the Commission, the temporary framework of public aid resources in order to support economy in the context of the ongoing Covid-19 epidemic (2020/ C91I/01) (Dz. Urz. UE C 91I of 20.03.2020, p. 1) constitutes public aid aiming at remedying serious disturbances in economy as well as the applied resolutions (Regulation of 2008 on reports). In this matter we should apply the Regulation of 2008 on reports as well as the Regulation of 2020 on reports. The discussed support, however, is not aid de minimis, the granting of which obligates the authority to document it with a certificate. (Kamiński, 2020) Thus, the authority has no obligation to issue certificates of granting the aid, either in case of natural persons or in case of legal persons and organisational units without legal personality, in case of applying the analysed preference. (Kamiński, 2020)

Proving the granted aid will also occur through placing it in report RB-27S column 13 "Consequences of municipality-granted reliefs", cancellations and exemptions in taxes and fees making the municipality's budget income (without statutory reliefs and exemptions), being Appendix 8 to the Regulation on budget reporting.

The entrepreneur benefitting from the prolongation under scrutiny should submit an appropriate form referring to public aid. The preference resulting from a resolution adopted on the basis of Article $15 \mathrm{q}$ of the Act on Covid is a form of granting public aid other than de minimis aid. (Dowgier, 2020b, p. 8) 
The taxpayer who meets the conditions for benefitting from prolonging tax payment instalments defined in the resolution under scrutiny has no obligation to submit a correcting declaration or tax information referring to the real estate tax. The obligation is in force if there are circumstances affecting the tax amount (Article 6 Paragraph 6 Act on local taxes ${ }^{3}$. In this case the tax authority is not obliged either to issue any tax decisions, where it would confirm the right to prolong the deadline of instalment payments. For there are no legal grounds in the Act on Tax Ordinance for issuing such a decision. The grounds cannot be introduced in the resolution adopted on the basis of Article $15 \mathrm{q}$ of the Act on Covid either. This would be against the automatic character of the payment deadline prolongation, which should refer to resolutions adopted on the basis of the aforementioned provision. This statement does not mean that the tax authority will have no instruments enabling it to verify if the taxpayer had the right to pay in the instalment within the deadline prolonged in a relevant resolution. The authority will be entitled to this possibility within the framework of proceedings carried out in order to issue a decision of proportional counting of the payment (Article 55 item 2 and Article 62 Paragraph 4 of the Act on Tax Ordinance) or a decision of counting the payment or overpayment as a sum towards the arrears and interests on late payment (Article 62 Paragraph 4 and Article $76 \mathrm{a}$ of the Act on Tax Ordinance). In these cases the tax authority is obliged to issue a decision, which can be subject to complaint. In the event where the tax authority decides that the taxpayer will make the payment after the primary payment deadline and simultaneously decides that no conditions of the taxpayer benefitting from the prolongation of the payment deadline resulting from a resolution adopted on the basis of Article $15 \mathrm{q}$ of the Act on Covid are met, the questioning of the legitimacy of benefitting from the prolonged deadline will involve issuing a relevant decision, which was mentioned above. On the other hand, in the case of undertaking a tax execution, the tax payer may put forward an argument that they meet the conditions for prolonging the payment deadline through raising an objection against the execution, i.e. the lack of obligation in Article 33 Paragraph 1 Point 1 of the Act on executive procedures in administration.

\subsection{Disadvantages resulting from tax resolutions adopted on prolonging payment deadlines of real estate tax instalments introduced on the grounds of the provisions of the Act on Covid}

Analysing the resolutions adopted by Regional Accounting Chambers referring to tax resolutions adopted by municipality councils, several irregularities in the resolutions of municipality councils were detected.

\footnotetext{
According to this Article natural persons are obliged to submit to a competent tax authority information about immovables and construction objects prepared on a specific form within 14 days of the occurrence of the circumstances justifying the emergence or expiration of a tax obligation referring to the real estate tax or from the day of the event mentioned in Paragraph 3. Furthermore, in accordance with Article 6 Paragraph 9 Point 2 of the Act on local taxes, legal persons, organisational units and companies without legal personality are obliged to relevantly correct declarations in the event mentioned in Paragraph 3, within 14 days of the day of its occurrence.
} 
First, it was found that the competence norm was infringed by an inappropriate prolonging of the payment deadline and determining the deadline for the day after September 30, 2020. Regional Accounting Chambers pointed out that the only competence norm allowing for prolonging payment deadlines in the real estate tax on the basis of a tax resolution is included in Article $15 \mathrm{q}$ of the Act on Covid, wherein this provision introduces its temporal limitation, i.e. no longer than September 30, 2020. Regional Accounting Chambers noted that the only competence norm enabling to prolong payment deadlines of the real estate tax on the basis of tax resolution is in Article 15q of the Act on Covid, but the provision introduces its temporal limitation, i.e. not later than September 30, 2020. The Act also underscores that in its resolution, the legislative body of the municipality deferred the deadlines of instalment payments for the months of April, May and June until October 31, 2021. It was pointed out that in the current legal order and taking into consideration the obligation of legislative bodies of local governments to act exclusively "on the basis and within the limits of statutory authorisations" - it is not possible to defer the payment deadline of real estate tax instalments by the legislative body of the municipality until the day later than September 30, 2020, because this limitation on local government legislative bodies' actions were imposed by the legislator in Article 15q Paragraph 1 of the Act on Covid. It was also noted that local law acts cannot be automatically issued without an explicit statutory authorisation, which is reflected in judicial decisions. It was also pointed out that the basis for making acts of local law is authorisation included in the law, which determines the dependent position in the hierarchy of law sources, as well as the fact that an act of a statutory status must always include authorisation (delegation) for a council to make an act of local law. Assessing it, one should bear in mind that the act cannot infringe either the regulation of the law including delegation for its establishing or the provisions of the Constitution of the Republic of Poland, as well as other laws remaining in an indirect or direct connection with the regulated matter (judgement of the SAC of July 11, 2018, judgement of the SAC of May 18, 2020, judgement of the PAC of February 6, 2019).

Secondly, there occurred situations where municipality councils introduced deadline prolongations of arrears instalments, or tax due sums the deadlines of which have expired at the moment of adopting the resolution. Certain municipality councils introduced records according to which the payment deadlines of real estate tax due in April, May and June 2020 were prolonged until September 30 to the entrepreneurs whose financial fluidity had deteriorated. Regional Accounting Chambers decided that the municipality councils had no grounds for adopting the resolution on April 29, 2020, on the basis of which it prolonged the payment deadline of real estate tax to the entrepreneurs, which was on April 15, 2020, so before the resolution.

Thirdly, Regional Accounting Chambers decided that certain municipality councils adopted faulty penal regulations in their resolutions. In general, as faulty were assumed cases when in the appendixes to the resolution, where the application forms were listed, these forms contained official statements of the applicant which were contra legem. For example, at the end of the application municipality councils introduced the following text: "Those who, making a statement intended to be evidence in judicial proceedings or other proceedings conducted on the basis of the Act, testify untruthfully or conceal the truth, 
shall be liable to imprisonment from 6 months to 8 years" (Article 233 of the Act on Penal Code). Regional Accounting Chambers observed that an entrepreneur's request (in fact being his statement) submitted on the basis of the resolution under scrutiny is not submitted in judicial proceedings or other proceedings conducted on the basis of the Act, and also, that no provision of law, especially the Act on Covid, gives the authority to impose upon the entrepreneur the obligation of submitting a statement including an instruction of penal liability defined in Article 233 of the Act on Penal Code.

In another resolution, Regional Accounting Chambers decided that, among other things, Article 15q of the Act on Covid was infringed in terms of Appendix 1 to the aforementioned Act, called "Application for extension of the deadline for the payment of real estate tax instalments of land, buildings and structures related to running a business", where the instruction contains the following clause: "I confirm this data with my own signature, warned of penal liability." Regional Accounting Chambers demonstrated that the aforementioned provision of the Act on Covid does not give any grounds for including the clause where the signatory of the application must declare that he/she was warned of penal liability in the application for using a certain tax preference submitted by a taxpayer. Moreover, it was underscored that the condition of liability for testifying untruthfully indicates a statutory regulation which provides for a possibility of receiving a declaration under the pain of penal liability.

Fourthly, certain municipality councils included in tax resolutions records that the prolongation of a payment deadline only occurs on the taxpayer's request, which should be submitted on the form determined by the mayor. Also, such resolutions were found in which municipality councils introduced conditions of the deferment of payment deadlines of a discriminatory character, furthermore, situations occurred where municipality councils did not have the resolutions they adopted published in the Official Journal of the province. Also, those records in the resolutions were recognised as faulty where only those entrepreneurs are entitled to the prolongation of the aforementioned payment deadline who run their businesses on the territory of the town and the municipality of Środa Śląska, as well as those employing/self-employing natural persons who work in the town and the municipality of Środa Śląska. It was observed that the introduction of the aforementioned condition is an infringement of the rule of free movement of workers referred to in Article 45 Paragraph 2 of the Treaty on the Functioning of the European Union. In accordance with the position of the European Commission, placing in aid programmes decisions reducing aid in connection with employing persons registered only in a particular area is an infringement of the rule of free movement of workers, referred to in the Treaty on the Functioning of the European Union. It was underscored that this one of the fundamental principles of the European Union means, most generally, the unfettered right of the European Union citizens to freely move within the whole territory of the European Union in order to start work as well as in search thereof. It was also noted that in the light of Article 45 Paragraph 2 of the Treaty on the Functioning of the European Union, the freedom of workers' movement means removal from the member states' legislature any forms of discrimination in terms of employment, remuneration and other working 
conditions of workers coming from other Member States, regardless of their citizenship. (Popławski, 2011, p. 954)

Regional Accounting Chambers also found unacceptable a situation where a record was introduced according to which a resolution enters into effect on the day of its passing without a simultaneous publication of this act.

\section{Conclusions}

The findings in this paper result in the following observations.

First, the instrument included in Article 15q of the Act on Covid authorises, but does not oblige, municipality councils to introduce a resolution on the basis of which the prolongation of the payment deadline of particular real estate tax instalments in 2020 occurs.

Second, the aforementioned competence rule could be applied in the following legal and temporal frames:

- the right referred exclusively to the real estate tax

- the mechanism could be applied exclusively in reference to payment deadlines of the instalments of the tax in 2020 for April, May and June 2020; thus, there were no grounds for prolonging payment deadlines of real estate tax due in other periods of 2020, as well as in subsequent years

- it was not allowed to prolong the payment deadline of the aforementioned instalments for a period later than September 30, 2020

Third, adopting a resolution on the basis of Article 15q of the Act on Covid on the part of the municipality resulted in consequences connected with the municipality declaring the granted public aid, as well as the obligation of reporting thereof within the framework of budget reporting in $\mathrm{RB}-27 \mathrm{~S}$ report. It is simultaneously important to note that the municipality introducing the prolongation of a payment deadline shall not bear any negative consequences therefor in the context of general subsidy. There are no grounds to assume that in this situation a real reduction of public resources occurs as a result of the application of the resolution under scrutiny.

Fourth, on the part of the taxpayer benefitting from the prolongation of the payment deadline of the real estate tax decided on the basis of Article 15q of the Act on Covid, there are also obligations to declare the public aid granted. The entity should submit a relevant form concerning public aid, which is a form of public aid other than de minimis aid. On the other hand, the taxpayer who meets the conditions of using the prolongation of tax instalment payment defined in the resolution under analysis has no obligation to submit a correction of the tax declaration or information referring to the real estate tax.

\footnotetext{
4 The author points out the defectiveness of certain discriminatory exemptions introduced by municipality councils in connection with, for instance, exempting entrepreneurs with businesses based on the territory of the municipality granting the exemption, or building owners registered as permanent residents in a particular municipality.
} 
Fifth, the analysis of resolutions adopted by regional accounting chambers, which referred to the verification of tax resolutions adopted by municipality councils on the basis of Article 15q of the Act on Covid, shows the following flaws, which resulted in the necessity of recognising the municipality councils' resolutions applied in part or in full as invalid:

- extending the payment deadline of real estate tax instalments on the day after September 30, 2020

- prolonging payment deadlines of the instalments of due sums being tax arrears at the moment of adopting the tax resolution

- prolonging faulty penal regulations involving, for instance, obliging the taxpayer to submit declarations on, among other things, his financial situation under pain of penal liability for false testimony

- prolonging a payment deadline on request of the taxpayer

- authorising a wójt (head of a municipality), a mayor (or a president of the city) to determine a model application form to be submitted by the taxpayer

- introducing conditions of discriminatory exemptions, for example exemption of taxpayers employing workers residing in a particular municipality

- failure to publish tax resolutions in the Official Journal of the province

\section{References}

Dowgier, R. (2020a). Nowe uprawnienia podatkowe rad gmin związane z pandemią COVID-19 [New tax powers of municipal councils related to the Covid-19 pandemic]. Przegląd Podatków Lokalnych i Finansów Samorządowych, 5.

Dowgier, R. (2020b). Weryfikacja prawa do zwolnienia oraz przedłużenia terminu płatności na podstawie uchwały rady gminy podjętej w związku z epidemią Covid-19 [Verification of the right to dismissal and extend the payment deadline based on a resolution of the commune council adopted in connection with the Covid-19 epidemic]. Przegląd Podatków Lokalnych i Finansów Samorządowych, 7.

Etel, L. (2020a). Pomoc podatkowa udzielana przez władzę lokalną przedsiębiorcom w czasach zarazy - co dały nowe regulacje? [ Tax assistance provided by local authorities to entrepreneurs in times of plague - thanks to new regulations?] Przegląd Podatków Lokalnych i Finansów Samorządowych, 8.

Etel, L. (Ed.) (2020b). Ordynacja podatkowa. Komentarz aktualizowany [Tax Ordinance. Comment updated]. LEX/el.

Kamiński, K. (2020). Czy udzielając ulgi podatkowej w związku z Covid-19 organ podatkowy powinien wydać podatnikowi decyzję oraz zaświadczenie o udzieleniu pomocy? [Should the tax authority provide the taxpayer with a decision and a certificate of assistance when providing a tax relief in connection with Covid-19?] QA 1461821, question answered on 31 May 2020 r., LEX. https://sip.lex.pl/\#/question-and-answer/622218813/ czy-udzielajac-ulgi-podatkowej-w-zwiazku-z-covid-19-organ-podatkowy-powinien-wydac-podatnikowi... $? \mathrm{~cm}=$ URELATIONS

Popławski, M. (2011). Uchwały podatkowe w nadzorze regionalnych izb obrachunkowych [Tax resolutions under the supervision of regional accounting chambers]. Wolters Kluwer, Warszawa.

Popławski, M. \& Charkiewicz, M. (2020a). Uprawnienia przedsiębiorcy będącego podatnikiem podatku od nieruchomości wynikające z przepisów tzw. tarczy antykryzysowej - wybrane kwestie [The rights of an entrepreneur who is a taxpayer of real estate tax resulting from the provisions of the so-called anti-crisis shield - selected issues]. In J. Salachna (Ed.), Konsument na rynku usług finansowych w okresie kryzysu [Consumer in the financial services market during the crisis]. Under publication. 
Popławski, M. \& Charkiewicz, M. (2020b). Wady uchwał podatkowych dotyczących przedłużania terminów płatności rat podatku od nieruchomości wprowadzanych w związku z Covid [Disadvantages of tax resolutions regarding the extension of terms of payment of real estate tax instalments introduced in connection with Covid]. Przegląd Podatków Lokalnych i Finansów Samorządowych, 10.

\section{Legal references}

EU: Treaty on the Functioning of the European Union - Consolidated versions of the Treaty on European Union and the Treaty on the Functioning of the European Union - Consolidated version of the Treaty on the Functioning of the European Union - Protocols - Annexes - Declarations annexed to the Final Act of the Intergovernmental Conference which adopted the Treaty of Lisbon, signed on 13 December 2007 - Tables of equivalences (Official Journal C 326, 26/10/2012 P. 0001 - 0390).

PL: 2020. Ustawy z dnia 31 marca 2020 r. o szczególnych rozwiązaniach związanych z zapobieganiem, przeciwdziałaniem i zwalczaniem Covid-19, innych chorób zakaźnych, a także wynikających z nich sytuacji kryzysowych oraz niektórych innych przepisów (Dz.U. of 2020, poz. 568 z poźn. zm.) [Act of March 31, 2020 on special solutions connected with preventing, counteracting and combatting Covid-19, other infectious diseases, as well as the crisis situation resulting therefrom, and certain other laws]. (Journal of Laws 2020, item 568 as amended) - referred to in this text as the Act on Covid.

PL: 1997. Ustawa z 29 sierpnia 1997 r. Ordynacja podatkowa (Dz.U. z 2017 r., poz. 201 as amended) [Act of August 29, 1997 on Tax Ordinance]. (Journal of Laws 2017, item 201 as amended] - referred to in this text as the Act on Tax Ordinance.

PL: Ustawa z 6 czerwca 1997 r. Kodeks Karny (Dz.U. of 2020 item 1444 as amended) [Act of June 6, 1997 on the Penal Code]. (Journal of Laws 2020, item 1444 as amended) - referred to in this text as the Act on Penal Code.

PL: 1991. Ustawa z dnia 12 stycznia 1991 r. o podatkach i opłatach lokalnych (Dz. U. z 2019 poz. 1170) [Act of January 12, 1991 on local taxes and fees]. (Journal of Laws 2019, item 170 as amended) - referred to in this text as the Act on local taxes.

PL: 1966. Ustawa z dnia 17 czerwca 1966 r. o procedurach administracji w egzekucji administracyjnej (Dz.U. of 2019 item 1438 as amended) [Act of June 17, 1966 on executive procedures in administration]. (Journal of Laws 2019, item 1438) - referred to in this text as the Act on executive procedures in administration.

PL: 2020. Rozporządzenie Rady Ministrów z dnia 4 czerwca 2020 r. zmieniające rozporządzenie w sprawie sprawozdań o udzielonej pomocy publicznej, informacji o nieudzieleniu takich dokumentów oraz o zaległościach przedsiębiorców w regulowaniu należności sektora finansów publicznych (Dz. U. z 2020, poz 1023) [The Regulation of the Council of Ministers of June 4, 2020 amending the Regulation on reports on provided public aid, information about failure to provide such aid as well as reports on entrepreneurs' arrears in paying sums due to the public finance sector]. (Journal of Laws 2016, item 1023) - referred to in this text as the Regulation of 2020 on reports.

PL: 2008. Rozporządzenie Rady Ministrów z dnia 7 sierpnia 2008 r. w sprawie sprawozdań z udzielonej pomocy publicznej, informacji o ich nieudzieleniu oraz raportów o zaległościach przedsiębiorców w regulowaniu należności sektora finansów publicznych (Dz. U. of 2016 poz. 1871) [The Regulation of the Council of Ministers of August 7, 2008 on reports on provided public aid, information about failure to provide such aid as well as reports on entrepreneurs' arrears in paying sums due to the public finance sector]. (Journal of Laws 2016, item 1871) - referred to in this text as the Regulation of 2008 on reports.

PL: Rozporządzenie Ministra Rozwoju z dnia 9 stycznia 2018 r. w sprawie sprawozdań budżetowych (Dz. U. item 1393) [Regulation of the Minister of Development of January 9, 2018, on budget reporting]. (Journal of Laws 2016, item 1393) - referred to in this text as the Regulation on budget reporting 2020.

PL: Naczelny Sąd administracyjny [Supreme Administrative Court] judgement of July 11, 2018, II OSK 675/18; Judgement of the SAC of May 18, 2020, I OSK 430/19 (not published).

PL: Wojewódzki Sąd Administraycjny [Provincial Administrative Court in Gdańsk] judgement of February 6, 2019, II SA/Gd 704/18 (not published). 